\title{
ANALISIS PENGARUH GOOD CORPORATE GOVERNANCE TERHADAP TAX AVOIDANCE
}

\author{
Afriyanti Hasanah ${ }^{1)}$, Cindy Oktami ${ }^{2)}$ Afdaleni ${ }^{3)}$ \\ 1) 2) Program Studi Akuntansi Manajerial, Politeknik Negeri Batam \\ Jl. Ahmad Yani, Batam Center, Batam 29461, Indonesia \\ ${ }^{3)}$ STBA Haji Agus Salim, Bukittinggi, Indonesia \\ Jl. Prof Bander Johan, Jangkak, Mandiangin Bukittinggi \\ ${ }^{1)}$ E-mail: afriyanti@ polibatam.ac.id \\ 2) E-mail: cindyoktami9@ gmail.com \\ ${ }^{3)}$ E-mail: afdaleni_09@yahoo.com
}

\begin{abstract}
This study aims to analyze the effect of Good Corporate Governance on tax avoidance.This study uses 4 variables for measuring Good Corporate Governance namely Institutional Ownership, Audit Quality, Company Size, and Political Connection. The population of this study are all manufacturing sector companies that have been listed on the Indonesia Stock Exchange (BEI) in the 2013-2017 period with a total final sample of 160 companies that have met the criteria. The samples in this study used nonprobability sampling method with purposive sampling technique in order to get a sample size of 32 companies. Data analysis technique used was simple linear regression analysis of each variable by using Eviews. The results showed that Institutional Ownership did not affect tax avoidance, while Audit Quality, Company Size, and Political Connection had an influence on tax avoidance.
\end{abstract}

Keywords: Tax Avoidance, Institutional ownership, Audit Quality, Company Size, and Political Connection

\begin{abstract}
ABSTRAK
Penelitian ini bertujuan untuk menganalisis pengaruh Good Corporate Governance terhadap tax avoidance. Penelitian ini menggunakan 4 variabel untuk pengukuran Good Corporate Governance yaitu kepemilikan institutional, kualitas audit, ukuran perusahaan, dan koneksi politik. Populasi dalam penelitian ini adalah seluruh perusahaan sektor manufaktur yang telah terdaftar di Bursa Efek Indonesia (BEI) periode 2013-2017 dengan total sampel akhir 160 sampel perusahaan yang telah sesuai dengan kriteria. Pengambilan sampel menggunakan nonprobability sampling dengan teknik purpose sampling. Jumlah sampel sebanyak 32 perusahaan. Teknik analisis data yang menunjukkan bahwa analisis regresi linear sederhana dengan menggunakan program Eviews. Hasil penelitian menunjukkan bahwa kepemilikan institutional tidak berpengaruh terhadap tax avoidance, sedangkan kualitas audit, ukuran perusahaan, dan koneksi politik memiliki pengaruh terhadap tax avoidance.
\end{abstract}

Kata Kunci: Tax Avoidance, Kepemilikan Institutional, Kualitas Audit, Ukuran Perusahaan, dan Koneksi Politik 


\section{PENDAHULUAN}

Pajak sangat berpengaruh dalam kelangsungan hidup kesejahteraan masyarakat dan yang terpenting pendapatan terbesar negara diperoleh sebagian besar dari pajak, akan tetapi kurangnya kesadaran wajib pajak untuk membayar pajak masih sering menjadi permasalahan hingga saat ini. Sebagian wajib pajak menganggap pembayaran pajak menjadi suatu beban dan pada akhirnya mereka melakukan cara agar bisa menghindari pajak.

Perbedaan mengenai analisis pajak antara pemerintah dan wajib pajak badan menimbulkan ketidakpatuhan yang dilakukan oleh pihak manajemen perusahaan. Bentuk dari ketidakpatuhan tersebut adalah upaya perusahaan untuk melakukan penghindaran pajak yang akan berdampak jelas pada penerimaan kas negara. Aktivitas tax avoidance ini suatu transaksi yang dilakukan oleh perusahaan untuk mengurangi beban pajak dengan memanfaatkan kelemahan-kelemahan yang ada dan tidak melanggar hukum tertentu.

Ketentuan pajak yang sudah tertuang pada Undang - Undang No.6 Tahun 1983 yang sudah dirubah menjadi Undang Undang No.16 Tahun 2009 tentang Ketentuan Umum dan Tata Cara Perpajakan (UU KUP). Dalam Undang Undang tersebut memberikan arahan bahwa pajak bersifat memaksa, dan menjadikan suatu beban tersendiri kepada wajib pajak. Dalam proses akuntansi pajak dikatakan biaya/beban yang harus dikurangi dengan laba bersih, pernyataan ini terkadang tidak sesuai dengan entitas bisnis yang ingin mendapatkan laba sebesar-besarnya. Dari sinilah faktor-faktor yang membuat para pengusaha-pengusaha untuk melakukan perbuatan penghindaran pajak. Ini semua dikarenakan masih adanya ketidaksempurnaan peraturan
Undang-Undang perpajakan sehingga dimanfaatkan oleh wajib pajak itu sendiri.

Penelitian ini merupakan pengembangan dari penelitian Vivi Adeyani (2015), yang berjudul The Effect of Good Corporate Governance on Tax Avoidance: An Empirical Study on Manufacturing Companies Listed in IDX Period 2010-2013 (Pengaruh Tata Kelola Perusahaan Yang Baik Terhadap Penghindaran Pajak: Studi Empiris pada Perusahaan Manufaktur yang Terdaftar dalam BEI Periode 2010-2013). Menurut (Adeyani, 2015) komite audit memiliki efek positif pada penghindaran pajak, dan kompensasi eksekutif, karakter eksekutif, ukuran perusahaan, proporsi kepemilikan institusioanl, dewan komisaris, dan kualitas audit tidak tidak ada pengaruh terhadap pengurangan penghindaran pajak.

Corporate governance suatu tata kelola perusahaan yang didalamnya berhubungan antara berbagai partisipan didalam perusahaan yang bertujuan untuk menentukan arah kinerja perusahaan (Haruman, 2008). Corporate governancesuatu perusahaan memiliki wewenang dalam proses pengambilan keputusan, sehingga termasuk dalam mengambil keputusan mengenai pajak perusahaan Winata dan Fenny (2014). Menurut Wahab dan Holland (2012) Perusahaan yang memiliki tata kelola yang buruk, aktivitas penghindaran pajak tidak bernilai bagi perusahaan, bahkan bisa mengurangi nilai perusahaan itu sendiri.

Budiman dan Setiyono (2012) dan Dewi dan Jati (2014) dalam penelitiannya menyatakan karakter eksekutif berpengaruh negatif pada tax avoidance. Peneliti selanjutnya Sabli dan Noor (2012) menyatakan dewan komisaris sebagai wakil atas pemegangn saham dan akan mendahulukan kepentingan pemegang saham, dengan cara mengutamakan kekayaaan perusahaan yang nilainya di pengaruhi oleh pajak. 
Selanjutnya penelitian Supadmi dan Suyadnya (2017) dan penelitian Maharani (2015) menunjukkan hasil yang beragam. Penelitian Supadmi dan Suyadnya (2017) dengan menggunakan variabel kualitas audit yang diukur menggunakan proksi ukuran KAP, audit fee, dan audit tenure terhadap GAAP ETR (Effective Tax Rate), yang hasilnya bahwa ukuran KAP berpengaruh positif terhadap GAAP ETR, audit fee berpengaruh negatif dan signifikan terhadap GAAP ETR, dan audit tenure tidak berpengaruh terhadap GAAP ETRBanyaknya perbedaan yang menjelaskan mengenai GCG terhadap tax avoidance sehingga peneliti tertarik untuk mengangkatnya lagi dengan menggunakan tahun yang terbaru 20132017 sehingga diharapkan dapat memberikan informasi yang terbaru bagi pemakai laporan keuangan dan tidak ada kesamaan yang menyeluruh antara penelitian ini dengan penelitian sebelumnya.

Dari latar belakang diatas penulis mengangkat judul penelitian ini dengan judul "Pengaruh Good Corporate Governance terhadap Tax Avoidance pada Perusahaan Manufaktur yang Terdaftar di Bursa Efek Indonesia”.

\section{KAJIAN TEORI, LITERATUR DAN PENGEMBANGAN HIPOTESIS}

\section{Teori Agensi}

Menurut teori agency cost Jesen dan Meckling (1976) hubungan agen sebagai kontrak di mana satu atau lebih orang (para pelaku) melibatkan orang lain (agen) untuk melakukan beberapa layanan atas nama mereka yang melibatkan mendelegasikan beberapa otoritas pengambilan keputusan kepada agen tersebut.

\section{Teori Sinyal}

Teori sinyal pertama kali diperkenalkan oleh Spence (1973). Signalling theory mengemukakan bagaimana seharusnya sebuah perusahaan memberikan sinyal kepada pengguna laporan keuangan. Sinyal tersebut berupa informasi apa yang telah dilakukan oleh manajemen untuk merealisasikan keinginan pemegang saham.

\section{PENGEMBANGAN HIPOTESIS}

\section{Pengaruh Kepemilikan Institutional terhadap Tax Avoidance}

Husnan (2001) dalam Hanum (2013) mengungkapkan bahwa 2 jenis kepemilikan dalam perusahaan di Indonesia yaitu perusahaan dengan kepemilikan menyebar dan perusahaan kepemilikan terkonsentrasi.

Penelitian yang dilakukan oleh Marita, Puspa dan Rahmawati (2013) menjelaskan adanya pengaruh positif variabel investor institutional terhadap ETR. Hasil penelitian Shafer dan Simmons (2006) juga menjelaskan kepemilikan institutional sangat penting dalam memainkan peran dalam mengawaasi, mendisiplinkan dan mempengaruhi manajer dalam manajemen pajak. Hal ini tidak sejalan dengan penelitian dari hasil penelitian Hanum (2013), Diantari dan Ulupui (2016), dan Masripah dkk (2016) menyimpulkan bahwa kepemilikan institutional tidak berpengaruh signifikan terhadap tax avoidance.Maka dari itu hipotesis $\mathrm{H} 1$ :

H1: Kepemilikan Institutional berpengaruh terhadap Tax Avoidance.

Pengaruh Ukuran Perusahaan terhadap Tax Avoidance

Ukuran perusahaan secara umum

dikatakan sebagai besar kecilnya suatu 
objek. Menurut Brigham dan Houston (2006) ukuran perusahaan adalah suatu ukuran atau skala besar kecilnya perusahaan yang di klasifikasikan berdasarkan cara yaitu dengan melihat ukuran pendapatan, total aset, dan total ekuitas.

Penelitian yang dilakukan oleh Sabli dan Md Noor (2012) menyatakan bahwa ukuran perusahaan berpengaruh negatif signifikan terhadap tax planning, sedangkan penelitian oleh Pohan (2009) bahwa ukuran perusahaan berpengaruh positif terhadap tax avoidance.Hal ini tidak sejalan dengan penelitian yang dilakukan oleh Tandean (2014) yang menyatakan ukuran perusahaan tidak bepengaruh signifikan terhadap tax avoidance. Maka dari itu hipotesis 2:

H2: Ukuran Perusahaan berpengaruh terhadap Tax Avoidance.

\section{Pengaruh Kualitas Audit terhadap Tax} Avoidance

Kualitas Audit merupakan segala kemungkinan yang dapat terjadi saat auditor mengaudit laporan keuangan client dan menemukan kesalahan atau pelanggaran yang terjadi dalam laporan keuangan dan melaporkannnya (Dewi dan Jati, 2014). Peningkatan dari transparansi terhadap pemegang saham dalam hal pajak semakin dituntut oleh otoritas publik (Sartori, 2010). Peneliti-peneliti terdahulu mengungkapkan bahwa Kualitas Audit memiliki pengaruh yang negatif terhadap Tax Avoidance ( Dewi dan Jati, 2014; Annisa dan Kurniasih, 2012). Hal ini tidak sejalan dengan penelitian Damayanti dan Susanto (2015) mengungkapkan bahwa kualitas audit tidak berpengaruh signifikan terhadap tax avoidance.Maka dari itu muncul lah hipotesis $\mathrm{H} 3$ :
H3: Kualitas Audit berpengaruh terhadap Tax Avoidance

Pengaruh Koneksi Politik tehadap Tax Avoidance

Perusahan dikatakan memiliki koneksi politik apabila minimal salah satu pemegang saham utam (orang yang memiliki paling tidak 10 persen dari total ha suara) atau salah satu pimpinan (CEO, presiden, wakil presiden, ketua, atau sekretaris) merupakan anggota parlemen, menteri atau memiliki relasi dengan politikus atau partai politik (Faccio, 2006). Penelitian yang dilakukan Nugroho (2011) menyatakan bahwa koneksi politik tidak berpengaruh signifikan terhadap tarif pajak efektif. Penelitian Adhikari et.al, (2006) menyatakan bahwa koneksi politik berpengaruh negatif dan signifikan terhadap tarif pajak efektif. Maka dari itu muncul lah hipotesis H4:

H4: Koneksi Politik berpengaruh terhadap Tax Avoidance.

\section{METODE PENELITIAN}

\section{Populasi dan Sampel}

Penelitian ini menggunakan data audited annual report perusahaan yang listed di BEI tahun 2013-2017 yang diperoleh dari laman www.idx.co.id pada perusahaan manufaktur. Teknik penarikan sampel yang digunakan adalah non-probability sampling dengan metode purposive sampling. Kriteria penarikan sampel: (1) Perusahaan sektor manufaktur yang listed di BEI 2013 - 2017, tidak mengalami Initial Public Offering (IPO), delisting, dan pindah ke sektor non manufaktur selama periode penelitian; (2) Menggunakan satuan mata uang Rupiah; (3) Perusahaan yang memiliki data yang memuat Kepemilikan Institusional, Kualitas 
Audit, Ukuran Perusahaan, dan Koneksi Politik.

\section{Variabel Dependen}

\section{Tax Avoidance}

Dalam penelitian ini tax avoidance diukur dengan menggunakan rumus Cash ETR, sumber Hanlon dan Heitzman (2010).

\section{Cash ETR $=\frac{\text { Current Tax Paid }}{\text { Pre-Tax Income }}$}

\section{Variabel Independen}

\section{Kepemilikan Institutional (KI)}

Dalam penelitian ini kepemilikan institutional diukur dengan menggunakan persentase rumus yang diambil dari jurnal penelitian oleh Khurana and Moser (2009) dapat diukur menggunakan rasio:

KI = Saham yang dimiliki institusi

ng diterbitkan

\section{Ukuran Perusahaan}

Ukuran perusahaan disini di proksikan dengan logaritma natural dari total aset sesuai dengan penelitian Budiman (2012), yang diambil dari total aset yang ada di dalam laporan tahunan yang diterbitkan oleh perusahaan.

(sumber:Dyreng, et. al (2010)

$$
\text { Firm Size }=L_{n} \text { Total Aset }
$$

\section{Koneksi Politik Komisaris Independen}

Dalam penelitian ini koneksi politik komisaris independen menggunakan dummy, dengan ketentuan jika suatu perusahaan memenuhi kriteria sebagai perusahaan yang memiliki koneksi politik maka akan diberi skor 1 dan jika tidak terdapat koneksi politik diberi skor 0 .
Penelitian ini kualitas audit dihitung dengan menggunakan variabel dummy,untuk menentukan kualitas audit dihitung dengan cara memberi nilai 1 kepada perusahaan yang diaudit oleh KAP The Big Four yaitu Price Waterhouse Cooper-PWC, Deloitte Touche Tohmatsu, KPMG, Ernst \& Young-E\&Y, selanjutnya jika tidak diaudit oleh KAP The Big Four akan diberi nilai 0 .

\section{Teknik Pengolahan dan Analisis Data}

Penelitian ini diolah menggunakan aplikasi statistik Eviews 9 untuk melakukan. Analisis data dilakukan dengan analisis statistik deskriptif, penentuan model estimasi (uji chow, uji hausman, dan uji langrange multiplier), uji asumsi klasik (uji multikolinearitas, uji heteroskedastisitas), dan uji hipotesis (analisis regresi data panel, koefisien determinasi, dan uji t).

Pengujian hipotesis pada penelitian ini akan di uji dalam regresi linear sederhana, model regresi yang digunakan dalam penelitian ini adalah sebagai berikut:

$$
\begin{gathered}
\mathbf{T A}_{\mathrm{it}}=\mathbf{B}_{0}+\mathbf{K I}_{\mathrm{it}}+\varepsilon \\
\mathbf{T A}_{\mathrm{it}}=\mathbf{B}_{0}+\operatorname{Siz}_{\mathrm{it}}+\varepsilon \\
\mathbf{T A}_{\mathrm{it}}=\mathbf{B}_{0}+\mathbf{K A}_{\mathrm{it}}+\varepsilon \\
\mathbf{T A}_{\mathrm{it}}=\mathbf{B}_{0}+\mathbf{K P K}_{\mathrm{it}}+\varepsilon
\end{gathered}
$$

Keterangan:

$\begin{array}{ll}\alpha & : \text { Konstanta } \\ \text { TA } & : \text { Tax Avoidance } \\ \text { KI } & \text { : Kepemilikan Institutional } \\ \text { Size } & : \text { Ukuran Perusahaan } \\ \text { KualAudit } & : \text { Kualitas Audit } \\ \text { KPKI } & : \text { Koneksi Politik }\end{array}$

Komisaris Independen

$\varepsilon$

: Standar Error

\section{Kualitas Audit (Kual Audit)}




\section{HASIL DAN PEMBAHASAN Karakteristik Data}

Data populasi yang digunakan dalam penelitian ini diambil dari Bursa Efek Indonesia selama tahun 2013-2017 dengan jumlah 717 perusahaan. Hasil analisis data berdasarkan kriteria purposive sampling yang telah ditetapkan sebelumnya dapat diketahui bahwa perusahaan yang melakukan delisting selama tahun observasi 9 perusahaan, yang tidak memuat laporan lengkap variabel dalam perusahaan sebanyak 464, perusahaan yang memakai mata uang selain rupiah sebanyak 45, dan laporan keuangan yang tidak di temukan sebanyak 39. Jadi, total sampel yang memenuhi syarat kriteria yang telah ditetapkan sebesar 32 perusahaan per tahun, sehingga jumlah observasi keseluruhan selama periode 2013-2017 adalah 160 perusahaan. Jumlah tersebut akan dijadikan sebagai acuan dalam mengukur setiap variabel untuk memperoleh hasil analisis melalui pengujian terhadap hipotesis yang diajukan.

\section{Statistik Deskriptif}

Hasil analisis statistik deskriptif terlihat pada Tabel 1 berikut:

\begin{tabular}{lccccc}
\multicolumn{5}{c}{ Tabel 1 Statistik Deskriptif } & \\
\hline Variabel & $\mathrm{N}$ & Minimum & Maximum & Mean & $\begin{array}{c}\text { Std. } \\
\text { Deviation }\end{array}$ \\
\hline Cash ETR & 160 & 0.00518 & 1.95 & 0.3286 & 0.29988 \\
\hline KI & 160 & 0 & 1.34 & 0.7340 & 0.28502 \\
\hline KPKI & 160 & 0 & 1 & 0.3187 & 0.46745 \\
\hline KualAudit & 160 & 0 & 1 & 0.5687 & 0.49680 \\
\hline Size & 160 & 11.4798 & 19.5046 & 14.892 & 1.83501 \\
\hline
\end{tabular}

Sumber: Olah data dengan Eviews 9

\section{Hasil Pengujian Asumsi Klasik}

Berdasarkan uji normalitas, multikolinearitas yang mengacu pada Gujarati (2006) dan uji heterokedastisitas yang mengacu pada Ghozali (2016) dapat disimpulkan data pada penelitian ini tidak mengalami permasalahan uji asumsi klasik.

\section{Hasil Uji Model Eviews}

Berdasarkan uji Chow dapat disimpulkan data pada penelitian ini tidak mengalami permasalahan uji asumsi klasik

\section{Uji Chow}

Menurut Basuki \& Prawoto (2016) terdapat 3 model estimasi data panel yaitu common effect, fixed effect, dan random effect. Dalam menentukan model estimasi terbaik antara common effect dan fixed effect maka dilakukan uji chow. Hasil uji chow pada penelitian ini menunjukkan bahwa lebih tepat menggunakan model common effect dibandingkan model fixed effect, selanjutnya akan dilakukan uji LM (Lagrange Multiplier).

\section{Uji Langrange Multiplier Test}

Uji LM ini dilakukan untuk menentukan model estimasi terbaik antara common effect dan random effect. Adapun hasil pengujian $\mathrm{H} 1-\mathrm{H} 4$ menunjukkan nilai probabilitas breusch-pagan lebihbsar dari 0,05 yang berarti bahwa penelitian ini memakai model common effect untuk persamaan regresinya.

\section{ANALISIS DATA}

Berdasarkan hasil pengujian, didapatlah persamaan regresi linier sederhana sebagai berikut :

CashETR $_{\mathrm{it}}=0,215623\left(\mathrm{~B}_{0}\right)+0,153985\left(\mathrm{KI}_{\mathrm{it}}\right)$

CashETR $_{\text {it }}=0,789740\left(\mathrm{~B}_{0}\right)-0,030960\left(\right.$ SIZE $\left._{i t}\right)$

CashETR $_{\mathrm{it}}=1,669776\left(\mathrm{~B}_{0}\right)+0,325696\left(\mathrm{KA}_{\mathrm{it}}\right)$

$\operatorname{CashETR}_{\mathrm{it}}=0,819948(\mathrm{Y})+0,337955\left(\mathrm{KPKI}_{\mathrm{it}}\right)$

Selanjutnya, dilakukan uji hipotesis antara variabel independen dan variabel dependen maka dapat dapat diambil ringkasannya pada berikut : 


\begin{tabular}{|c|c|c|c|c|}
\hline & Hipotesis & Sig. & t-Statistic & Hasil \\
\hline & Kepemilikan & & & \\
\hline H1 & $\begin{array}{l}\text { Institutional } \\
\text { terhadap tax } \\
\text { avoidance }\end{array}$ & .0648 & 1859687 & $\begin{array}{c}\text { Tidak } \\
\text { Terdukung }\end{array}$ \\
\hline H2 & $\begin{array}{l}\text { Ukuran } \\
\text { Perusahaan } \\
\text { terhadap tax } \\
\text { avoidance }\end{array}$ & .0164 & (2425237) & Terdukung \\
\hline H3 & $\begin{array}{l}\text { Kualitas Audit } \\
\text { terhadap tax } \\
\text { avoidance }\end{array}$ & .0000 & 8.366142 & Terdukung \\
\hline H4 & $\begin{array}{l}\text { Koneksi } \\
\text { Politik } \\
\text { terhadap tax } \\
\text { avoidance }\end{array}$ & .0000 & 5.996471 & Terdukung \\
\hline
\end{tabular}

**Signifikansi pada level $5 \%$

Sumber: Data diolah sendiri

Tabel 2 Ringkasan Hasil Uji Hipotesis

\section{Pengaruh Kepemilikan Institutional terhadap Tax Avoidance}

Berdasarkan hasil dari pengujian hipotesis $\mathrm{H} 1$ yang telah dijelaskan pada table 4.8 menyatakan tidak ada pengaruh signifikan antara kepemilikan institutional terhadap tax avoidance. Sehingga dalam penelitian H1 tidak terdukung. Hasil penelitian ini dapat dilihat bahwa tidak ada pengaruh antara kepemilikan institutional dengan tax avoidance, karena kepemilikan institutional secara umum tidak ada kaitannya dengan penghindaran pajak dikarenakan kepemilikan institutional tidak berperan langsung dalam perusahaan hanya saja mempunyai hak milik yang tidak berpengaruh secara langsung ke tata kelola perusahaan dan penghindaran pajak. Kepemilikan institutional hanya berperan sebagai pihak yang memonitor atau mengawasi dan tidak berperan aktif dalam pengambilan suatu keputusan yang ada di perusahaan tersebut.

Hasil penelitian menyatakan kepemilikan institusional tidak berpengaruh terhadap tax avoidance. Semakin besar kepemilikan instutional dalam perusahaan akan mengurangi tindakan tax avoidance dikarenakan adanya tanggung jawab perusahaan kepada pemegang saham. Penyebab dari kepemilikan institusional tidak berpengaruh terhadap tax avoidance diduga karena pemilik institusional lebih mementingkan untuk memaksimalkan kesejahteraannya dalam laba yang akan mereka peroleh semakin besar atau kecilnya kepemilikan institusional tidak mempengaruhi tax avoidance.

Hasil penelitian ini sejalan dengan hasil penelitian yang dilakukan oleh Andeyani (2015) Penelitian lainnya juga sejalan dengan hasil ini yaitu yang dilakukan Pohan (2009), Dewi dan Jati (2014), Annisa dan Kurniasih (2012) yang mejelaskan tidak adanya pengaruh antara kepemilikkkan institusioanl dengan penghindaran pajak, Hasil penelitian namuntidak sejalan dengan hasil penelitian yang dilakukan oleh Pranata, Puspa dan Herawati (2013) yang menjelaskan ada pengaruh yang signifikan antara kepemilikan institusional dengan tax avoidance.Hasil penelitian lainnya banyak juga yang tidak sependapat seperti hasil penelitian.

\section{Pengaruh Ukuran Perusahaan terhadap Tax Avoidance}

Berdasarkan hasil pengujian hipotesis $\mathrm{H} 2$ yang telah dijelaskan di tabel 4.9 yang menyatakan tidak ada pengaruh yang signifikan antara ukuran perusahaan terhadap tax avoidance. Sehingga dalam penelitian ini $\mathbf{H 2}$ terdukung. Pengujian ini dilakukan untuk melihat adanya pengaruh ukuran perusahaan terhadap tax avoidance.

Hasil penelitian ini menunjukkan ukuran perusahaan berpengaruh kepada penghindaran pajak karena semakin besar perusahaan maka akan semakin kecil CETR yang dimilikinya, perusahaan besar 
mampu mengola sumber daya dengan baik, maka dari itu besar dan kecilnya perusahaan mampu menggambarkan tingkat penghindaran pajak yang perusahaan tersebut lakukan. Ukuran perusahaan mampu mengukur adanya penghindaran pajak yang dilakukan oleh perusahaan.

Hasil ini sejalan dengan peneliti Kurniasih dan Sari (2013); Richardson dan Lanis (2007) yang menjelaskan ukuran perusahaan sangat berpengaruh signifikan terhadap tax avoidance.Hasil ini tidak sejalan dengan penelitian Andeyani (2015) yang menjelaskan bahwa ukuran perusahaan tidak memiliki bukti yang cukup terhadap efek penghindaran pajak. Penelitian lainnya yang sejalan dengan hasil ini adalah Dewi dan Jati (2014) yang menjelaskan bahwa tidak ada pengaruh signifikan ukuran perusahaan terhadap tax avoidance, karena perusahaan besar atau kecil memiliki kewajiban yang sama untuk membayar pajak.

\section{Pengaruh Kualitas Audit terhadap Tax Avoidance}

Berdasarkan hasil dari pengujian hipotesis $\mathrm{H} 3$ yang telah dijelaskan di tabel 4.10 yang menyatakan tidak ada pengaruh yang signifikan antara kualitas audit terhadap tax avoidance. Hal ini dijelaskan dengan nilai signifikan lebih kecil dari tingkat kepercayaannya, sehingga dinyatakan H3 terdukung. Pengujian ini dilakukan untuk melihat adanya pengaruh kualitas audit terhadap tax avoidance.

Hal ini sejalan dengan penelitian penelitian Maharani (2015) yang menyatakan bahwa kualitas audit berdasarkan ukuran KAP berpengaruh positif terhadap penghindaran pajak melalui Cash ETR. Ukuran KAP yang melakukan audit tidak menjadi pedoman dalam mendeteksi sebuah perusahaan melakukan praktik penghindaran pajak. Ukuran KAP Big Four ataupun Non Big Four tidak mempengaruhi banyak atau tidaknya kas yang dikeluarkan untuk biaya pajak, sehingga walaupun perusahaan menggunakan jasa auditor yang termasuk ke dalam Big Four, tidak bisa diindikasikan penghindaran pajak perusahaan tersebut menurun. Perusahaan yang diaudit oleh KAP Big Four memang akan lebih cenderung dipercayai oleh fiskus karena KAP tersebut memiliki reputasi yang baik, namun jika perusahaan bisa memberikan keuntungan dan kesejahteraan yang lebih baik terhadap KAP yang mempunyai reputasi yang baik, bisa saja KAP tersebut melakukan kecurangan untuk memaksimalkan kesejahteraan perusahaan. Penelitian ini tidak sejalan yang dilakukan oleh Damayanti dan Susanto (2015) yang menyatakan tidak terdapat pengaruh antara ukuran KAP terhadap penghindaran pajak melalui Cash ETR..

\section{Pengaruh Koneksi Politik terhadap Tax Avoidance}

Hasil dari pengujian hipotesis $\mathrm{H} 4$ yang telah dijelaskan pada di tabel 4.11 yang menyatakan tidak ada pengaruh yang signifikan antara koneksi politik terhadap tax avoidance. Hal ini di jelaskan dengan nilai signifikan lebih kecil dari tingkat kepercayaannya sehingga dinyatakan bahwa dalam peneltian ini $\mathrm{H} 4$ terdukung. Pengujian ini dilakukan untuk melihat adanya pengaruh antara koneksi politik dengan tax avoidance.

Koneksi politik juga menciptakan perusahaan yang memiliki tata kelola yang baik. Perusahaan yang mempunyai koneksi 
politik mempunyai tarif yang lebih kecil karena adanya kebijakan khusus yang memberikan kepada perusahaan tertentu yang mempunyai perencanaan lebih baik sehingga lebih efektif dalam menurunkan pembayaran pajak (Fraccio,2006). Hasil ini membuktikan bahwa koneksi poltik berpengaruh kepada tax avoidance.

Hasil ini di dukung oleh adhikari et al ., (2006) yang menjelaskan bahwa koneksi politik negative dan signifikan terhadap tax avoidance .Penelitian lainnya tidak sependapat dengan hasil ini seperti penelitian Nugroho (2011) yang menjelaskan tidak ada pengaruh antara koneksi politik terhadap tarif pajak efektif.

\section{KESIMPULAN DAN SARAN KESIMPULAN}

Kesimpulan dari penelitian ini adalah:

a. Kepemilikan institutional tidak berpengaruh terhadap tax avoidance karena kepemilikan institutional hanya berperan sebagai pengawas dan memonitor tidak berperan aktif dalam pengambilan keputusan yang akan diambil oleh perusahaan.

b. Ukuran perusahaan berpengaruh kepada tax avoidance karena dikatakan bahwa besar atau kecilnya suatu perusahaan dapat berpengaruh terhadap tingkat penghindaran pajak.

c. Kualitas audit berpengaruh secara signifikan terhadap tax avoidance karena semakin bagus perusahaan tersebut diudit dengan audit yang berkualitas maka semakin kecil tingkat penghindaran pajak yang akan dilakukan oleh perusahaan.

d. Koneksi politik berpengaruh secara signifikan terhadap tax avoidance, karena perusahaan yang memilki koneksi politik lebih cendrung memiliki tata kelola perusahaan yang baik dan jika sudah memilki tata kelola perusahaan yang baik maka penghindaran pajak akan semakin rendah.

\section{Saran}

Terdapat beberapa saran untuk penelitian selanjutnya:

a. Penelitian selanjutnya sebaiknya menggunakan proksi selain yang penulis teliti.

b. Peneltian selanjutnya sebaiknya menambah kurun waktu yang lebih panjang lagi agar dapat menghasilkan data yang sempurna.

c. Sebaiknya penelitian selanjutnya menambahkan variabel lainnya yang dapat berpengaruh kepada penghindaran pajak.

d. Untuk peneliti selanjutnya sebaiknya menambahkan variabel kontrol untk melihat lebih dalam lagi yang diteliti.

e. Menambahkan kriteria sampel sesuai dengan penggunaan penelitian.

\section{Daftar Pustaka}

Adhikari, A. D. (2006). Public Policy, Political Connections, and Effective Tax Rates: Longitudinal Evidence From Malaysia. Journal Of Accounting And Public Policy, 25-(5).

Andreoni, J., Erard, B., \& Feinstein, J. (1998). Tax compliance. Journal of Economic Literature, 36:818-860.

Annisa, N. A., \& Kurniasih, L. (2012). Pengaruh Corporate Governance Terhadap Tax Avoidance. Jurnal Akuntansi dan Auditing, 95-189.

Budiman, Judi, \& Setiyono. (2012). Pengaruh Karakter Eksekutif Pada Penghindaran Pajak. Universitas Islam Sultan Agung, 130. 
Desai, M. A., \& Dharmapala, D. (2007). Corporate Tax Avoidance adn Firm Value. Journal of Financial Economics, 67.

Dewi, Kristiana, N. N., \& Jati, I. K. (2014). Pengaruh Karakter Eksekutif , Karakteristik Perusahaan, dan Dimensi Tat Kelola Perusahaan yang Baik Pada Tax Avoidance yang Terdaftar di Bursa Efek Indonesia. Bali: Fakultas Ekonomi Universitas Udayana.

Diantari, Putu Rista dan Ulupui IGK Agung. (2016). Pengaruh Komite Audit, Proporsi Komisaris Independen dan Proporsi Kepemilikan Institusional terhadap Tax Avoidance. E-jurnal Akuntansi Universitas Udayana, 16 (1) : 702732.

Ernest, M. R. (2006). Perpajakan Konsep, Teori, dan Isu.

Ernest, R. (2006). Buku perpajkan konsep, teori dan isu.

Faccio, M. (2006). Politically Connected Firms. The American Economoic Review, 369-386

Ghozali, I. (2001). Aplikasi Analisis Mutivariate dengan Program IBM SPSS. Semarang: Badan Penerbit Universitas Diponegoro.

Ghozali, I. (2016). Aplikasi Analisis Mutivariate dengan Program IBM SPSS 23. Semarang: Badan Penerbit Universitas Diponegoro.

Hanlon, M., \& Heitzman, S. (2010). A Review of Tax Research. Journal Of Accounting and Economic, 165.

Hanum, H.R. (2013). Pengaruh Karateristik Corporate Governance Terhadap Effective Tax - 52 (ETR). Jurnal Akuntansi : 1-5‘..

Haruman, T. (2008). Pengaruh Struktur Kepemilikan Terhadap Keputusan Keuangan dan Nilai Perusahaan. Simposium Nasional Akuntansi, XI, 70.
Khurana, I. K., \& Moser, W. J. (2018, September 2). Retrieved from Institutional Ownership and Tax Aggressiveness: www.SSRN.com

Kurniasih, T., \& M, S. (2013). Pengaruh ROA,Leverage, Corporate Governance, Ukuran Perusahaan, dan Kompensasi Rugi Fiskal terhadap Tax Avoidance. Buletin Studi Ekonomi, 1-84.

Lanis, R. d. (2011). The Effect of Board of Director Composition on Corporate Tax Aggressiveness . Journal of Accounting dan Public Policy, 5070.

Leuz, C., \& Oberholzer, -G. F. (2006). Political Relationships, Global Financing, and Corporate Transparency. Evidence From Indonesia Journal of Financial Economics, 411-439.

Lukviarman , N. (2006). Etika Bisnis Tidak Berjalan di Indonesi: Ada Apa Dalam Corporate Governance? Journal Siasat Bisnis, 139-156.

Maharani, D. (2015). Pengaruh Kualitas Auditor Eksternal dan Komite Audit terhadap Tax Avoidance. Diponegoro Journal of Accounting, 1-67.

Maharani, I. G., \& K.A, S. (2014). Pengaruh Corporate Governance, Profitabilitas, dan Karateristik Eksekutif Pada Tax Avoidance. EJurnal Akuntansi, 525-539.

Masripah, dkk. (2016). Controlling Shareholder and Tax Avoidance: Family Ownership and Corporate Governance. Journal of Business Studies, 8 (3) : 1-14.

Nugroho, A. A. (2011). Pengaruh Hubungan Politik dan Reformasi Perpajakan Terhadap Tarif Pajak Efektif pada Perusahaan yang Terdaftar di Bursa Efek Indonesia 2008-2009. Skripsi Depok. FEUI.

Prakosa, K. (2014). Pengaruh profitabilitas, kepemilikan keluarga 
dan corporate governance terhadap penghindaran pajak di Indonesia. Simposium Nasional Akuntansi XVII, 62-90.

Pohan, H. T. (2009). Analisis Pengaruh Kepemilikan Institusi, Rasio Tobin Q, Akrual Pilihan, Tarif Efektif Pajak, dan Biaya Pajak Ditunda Terhadap Penghindaran Pajak Pada Perusahaan Publik. Jurnal Informasi, Perpajakan, Akuntansi dan Keuangan Publik. Vol.4, No.2,, 113-135.

Republik Indonesia. 2006. Peraturan Bank Indonesia No 8/14/PBI/2006 tentang pelaksanaan good corporate governance.

Republik Indonesia. 2007. UndangUndang KUP No. 28 Tahun 2007 tentang Pajak.

Republik Indonesia. 2009. UndangUndang No. 16 Tahun 2009 tentang Ketentuan Umum dan Tata Cara Perpajakan.

Reza, F. (2012). Pengaruh Dewan Komisaris dan Komite Audit Terhadap Penghindaran Pajak. Skripsi Universitas Indonesia.

Sabli, N., \& Noor, M. R. (2012). Tax Planning and Corporate Governance . Proceeding International Conference on Business and Economic Research. 967-978.

Sartori, Nicola. (2010). Effect of Strategic Tax Behaviors on Corporate Governance. www.ssrn.com.

Setiana, D., \& Setyowati, W. (2014). Pengaruh corporate governance , kompensasi rugi fiskal, ROA,leverage dan ukuran perusahaan terhadap tax avoidance. Journal Accounting and Banking 3 (2), 48-65.

Spence, M. (1973). Job Market Signalling.

The Quarterly Journal of Economics, 87, (3), pp. 355-374.

Shimmons, R., \& Shafer, W. (2006). Social Responsibility, machiavellianism and tax avoidance. A Study of Hong Kong Tax Professionals, 5.

Siallagan, H., \& Machfoedz, M. (2006). Mekanisme Corporate Governance Kualitas Laba dan Nilai Perusahaan. Simposium Nasional Akuntansi, IX.

Sudharmono, J. (2004). Buku Panduan Implementasi GCG Self Assessment.

Supadmi, N., \& Suyadnya, I. (2017). Pengaruh Ukuran KAP, Audit Fee, dan Audit Tenure pada Agresivitas Pajak. E-Jurnal Akuntansi Universitas Udayana, 1131-1159.

Tandean, V. A. (2015). The Effect of Good Corporate Governance on Tax Avoidance: An Empirical Study on Manufactruring Companies Listed in IDX period 2010-2013. emeral insight, 28-38.

Wahab, A., \& Holland, K. (2012). Tax Planning, Corporate Governance and Equity Value. The British Accounting Review, 44(2), 111124.

Widarjono, A. (2009). Ekonometrika Pengantar dan Aplikasinya Edisi Ketiga. Yogyakarta: Ekonisia.

Winata, F. (2014). Pengaruh Corporate Governance Terhadap Tax Avoidance Pada Perusahaan Yang terdaftar di Bursa Efek Indonesia. Tax and Accounting Review, 4(1), 162. 